УдК 328.185 (510)

\section{МОРАЛЬНО-ЕТИЧНІ ОСНОВИ \\ ФІЛОСОФСЬКИХ ПОГЛЯДІВ НА КОРУПЦІЮ У ПОЛІТИЧНІЙ ТРАДИЦІЇ КИТАЮ}

Маслова Анастасія Олександрівна

магістр міжнародних відносин,

Інститут міжнародних відносин та зовнішньої політики

Університет Фудань,

м. Шанхай, Китайська Народна Республіка

ORCID: 0000-0002-0014-3592

17210170456@fudan.edu.cn
Надіслано:

14.03.2019

Рецензовано:

20.03.2019

Прийнято:

10.04.2019

Мета статті - з'ясувати сутність морально-етичних поглядів у китайській філософській думці на виникнення корупції, на роль в них міжособистісних відносин; здійснити огляд культурного тла корупції; розглянути корупцію сучасного Китаю 3 точки зору конфуціанської традиційної політичної культури. У дослідженні застосовано комплекс методів - аналіз, синтез, логічний, історико-порівняльний, культурологічний, системно-структурний - для розгляду стану наукового висвітлення теми,походження корупції та її зв'язку із соціокультурними факторами.

На основі з'ясування політичного й культурного походження корупції як явища та осмислення корупції сучасного Китаю 3 погляду конфуціанської традиційної політичної культури зроблено висновки про те, що виникнення корупції пов'язане із конкретними соціокультурними факторами й причинами, які беруть початок у міжособистісних відносинах. Першоджерелом корупції названо глибоко вкорінені в політичній економіці культурні гени. Водночас зазначено, що оновлення ідей у суспільстві проходить повільно й не має чітких перспектив реалізації;формування середовища верховенства права вимагає тривалого процесу; подолання корупції - актуальне завдання і в суспільному житті, і в сфері культури та науки.

Ключові слова: корупція; міжособистісні відносини; політична культура; китайське суспільство. 
Maslova Anastasiia, MA in International Relations, Fudan University, Shanghai, China

The moral and ethical basis of the philosophical views on corruption in the political tradition of China

The purpose of the article is to clarify the essence of moral and ethical views in Chinese philosophical thought on the corruption emergence, as well as the role of interpersonal relations in it; review the cultural background of corruption; consider the corruption of modern China from the point of view of Confucian traditional political culture. The study applies a complex of methods - analysis, synthesis, logical, historical-comparative, cultural, system-structural - to examine the state of the scientific coverage of the topic, the origin of corruption and its sacred factors with sociocultural factors.

Based on the political and cultural origin of corruption's clarification as a phenomenon and understanding of the modern China corruption from the point of view of Confucian traditional political culture, the author draws conclusions that the emergence of corruption is associated with specific sociocultural factors and causes that originate in interpersonal relations. Cultural genes deeply rooted in the political economy are called the primary source of corruption. At the same time, it is noted that the renewal of ideas in society is slow and does not have clear prospects for implementation; the formation of an environment of the rule of law requires a long process; overcoming corruption is an urgent task both in public life, and in the sphere of culture and science.

Key words: corruption; interpersonal relations; political culture; Chinese society.

Маслова Анастасия Александровна, магистр международных отношений, Институт международных отношений и внешней политики, Университет Фудань, г. Шанхай, Китайская Народная Республика

\section{Морально-этические основы философских взглядов на коррупцию в политической традиции Китая}

Цель статьи - выяснить суть морально-этических взглядов в китайской философской мысли в возникновении коррупции, а также на роль, которые межличностные отношения играют в ней; совершить обзор культурного фона коррупции; рассмотреть коррупцию современного Китая с точки зрения конфуцианской традиционной политической культуры. В исследовании применен комплекс методов - анализ, синтез, логический, историкосравнительный, культурологический, системно-структурный $\quad$ - для рассмотрения состояния научного освещения темы, происхождения коррупции ее связи с социокультурными факторами.

На основе выяснения политического и культурного происхождения коррупции как явления и осмысления коррупции современного Китая с точки 
зрения конфуцианской традиционной политической культуры сделано выводы о том, что возникновение коррупции связано с конкретными социокультурными факторами и причинами, которые берут начало в межличностных отношениях. Первоисточником коррупции названы культурные гены, глубоко укоренившиеся в политической экономике. В то же время отмечено, что обновление идей в обществе происходит медленно и не имеет четких перспектив реализации; формирование среды верховенства права требует длительного процесса; преодоление коррупции - актуальная задача и в общественной жизни, и в сфере культуры и науки.

Ключевые слова: коррупция; межличностные отношения; политическая культура; китайское общество.

\section{Вступ}

Корупція є загальною проблемою, 3 якою стикається людство від найдавніших часів, коли з'явилися перші державні утворення. Проте, в небагатьох суспільствах уявлення про неї мають достатньо давні традиції у філософській та політичній культурі. Китайська традиція у цьому сенсі $\epsilon$ найбільш сталою, не дивлячись навіть на трансформацію у ХX ст., пов'язану із комуністичним пануванням. I найбільший інтерес вона представляє 3 точки зору протиставлення уявленням, поширеним у західній цивілізації.

\section{Аналіз останніх досліджень}

До теми корупції неодноразово зверталися дослідники різних наукових напрямів. В багатьох творах цю тему було розглянуто в контексті загальносвітових процесів, зокрема серед них можна згадати праці С. Хантінгтона, Р. Степнхерста, С. Дж.Кпунде, C.Р.Акерман та ін. Серед найважливіших же праць, в яких було звернено увагу цю тему безпосередньо в контексті розвитку Китаю варто виокремити дослідження Ван Хуніна «Антикорупційний досвід Китаю» (2008), Лю Чуня «Пастка влади та обмеження корупції в західних країнах» (1998), Лінь Піня «Корупція та обмеження влади» (1997) та Хе Цзенке «Злоякісна пухлина політики: дослідження корупції в країнах, що розвиваються» (2008).

\section{Формулювання цілей статті}

Метою статті $€$ з'ясування змісту морально-етичної філософської концепції сутності корупції у китайській політичній традиції, а також осмислення корупції сучасного Китаю з погляду конфуціанської традиційної культури.

\section{Виклад основного матеріалу}

Корупція $\epsilon$ складним соціальним явищем, i існування залежить не тільки від поточного політичного й економічного середовища, вона також має нерозривний зв'язок з історичними та культурними традиціями. Чи не 
найбільш послідовно ми це бачимо на прикладі розвитку китайської культури. У традиційній китайській філософії значне місце відводиться розгляду ролі міжособистісних відносин у суспільних процесах, у т. ч. й стосовно виникнення та розвиту корупції як явища. Зростаюча ж роль Китаю на світовій арені спонукає Україну все більше уваги приділяти не лише стосункам 3 нею, але й вивченню її досвіду у боротьбі із корупцією (Troyan 2018).

Міжособистісні відносини мають різних посередників, різні прояви та форми реалізації залежно від культурного контексту. У західному суспільстві люди реалізують міжособистісні відносини типу «емоційний досвід та соціальне спілкування»; натомість у східному суспільстві, зокрема в китайському, особливо звертають увагу на міжособистісні відносини «особисті емоції та соціальна оцінка» (Wang, 1999, p.236). Міжособистісні відносини Китаю характеризують три аспекти: міжособистісні відносини на рівні родинного кола, міжособистісні відносини на рівні родинного кола та міжособистісні відносини, що базуються на вигоді.

1. Міжособистісні відносини на рівні родинного кола. Китай здавна відомий як традиційне суспільство: сільськогосподарське виробництво було в ньому основним складником життя і засобом виживання, а прив'язаність до землі зумовила найбільш значущі національні риси й характер китайської нації, для якої земля - основна годувальниця. У такому суспільстві люди створюють села й народності, із покоління в покоління, живучи в своєму мініатюрному суспільстві; рік за роком, день за днем обробляючи землю, вони добре знають один одного, наче одна сім'я. Отже, концепція сімейного зв'язку та кровної спорідненості була глибоко вкорінена в ментальність кожної окремої людини. Погляди китайців на родинні стосунки, що характеризуються висловами «кров густіша за воду», «глибокий зв'язок між братами», «нащадки одного предка», зумовлюють сприйняття китайцями сімейних (або подібних сімейним) відносин як найбезпечніших i найбільш прийнятних міжособистісних стосунків (Wu, Yang, 2001, p.55). Внаслідок цього поняття сімейної свідомості природно стає основним психологічним орієнтиром міжособистісних стосунків. Саме цей психологічний орієнтир змушує посадових осіб нести відповідальність та здійснювати обов'язок перед людьми, глибоко залученими в міжособистісні взаємини, що грунтуються на поняттях сім'ї та кровних взаємин. Якщо вони ухиляються від цього зобов'язання й відповідальності, це означає розрив 3 усією мережею спорідненості. Томучиновники використовують власну владу, щоб безпосередньо або опосередковано «піклуватися» про своїх дітей і родичів та їхню особисту вигоду. Саме цим пояснюються такі відомі явища, як «навчатися за допомогою зв'язків», «шукати роботу через знайомства», «просування по кар'єрній драбині через знайомства» тощо (Wu, Yang, 2001, p. 56). 
2. Змішані міжособистісні відносини. Зі змінами часу й суспільства люди поступово долають обмежувальні рамки землеробства, кровних зв'язків, скупченості, закритості й застою, натомість залучаються до широкої сфери діяльності суспільства і чиновничої служби. Через те, що люди все ще не могли переступити через своє усвідомлення сімейної спорідненості, для того, щоб знайти почуття приналежності, щоб отримати турботу, допомогу й безпеку в роботі і житті, щоб у критичний час було кому захистити їхні інтереси, формуються нові змішані міжособистісні відносини, які засновані на сімейних відносинах та $є$ результатом розширення сімейного кола (Jiang, 2001, p. 24). Змішані міжособистісні відносини - більш складні й розгалужені, вони переважно стосуються міжособистісних стосунків індивіда поза сім'єю, котрі дають йому змогу мати тісний зв'язок із суспільством, що зазвичай включає в себе однокласників, друзів, вчителів, студентів і родичів чиновника. Такі стосунки також включають людей, які лише опосередковано пов'язані з чиновником, наприклад, друзі дружини (чоловіка), друзі дітей, друзі родичів та ін.

3. Міжособистісні відносини, що базуються на вигоді. 3 точки зору ринкових операцій в економіці, переслідування вигоди в міжособистісних відносинах $\epsilon$ раціональною поведінкою. У процесі спілкування людина зазвичай піклується тільки про власні інтереси в якості відправної точки, тому для того, щоб збалансувати інтереси, обидві сторони у спілкуванні базуються на принципі «порівняної переваги», таким чином вигода та вклад обох сторін урівноважуються (Wu, 2008, р.36). Оскільки такі грунтовані на вигоді відносини поширюються на всі сфери життя й суспільства, доки у відносинах обох сторін існує певна вигода, легко встановлюються відносини «влада-гроші» або «влада-влада», а відносини взаємної вигоди та взаємного використання між двома сторонами неминуче призводять до корупції (Wu, 2008, p. 38). Саме тому й зародилася корупція, викликана наявністю вигоди міжособистісних відносин, а їі прояви в сучасному суспільстві стають все більш масштабними й помітними.

У довготривалому феодальному суспільстві Китаю конфуціанська школа, представлена Конфуцієм і Менцзи, створила традиційну політичну культуру, що через різні механізми глибоко вкоренилася в ідеї, поведінку, звичаї, вірування, мислення та емоції людей. Ця культура давно стала керівним принципом і базовим орієнтиром, якими люди усвідомлено чи не усвідомлено керуються, коли мають справу 3 різними життєвими ситуаціями та відносинами. Саме на цій психологічній моделі утворився стійкий національний характер китайської нації. Тому навіть сьогодні, з бурхливим розвитком соціалістичної модернізації, усе ще чітко окреслюється вплив традиційної політичної культури конфуціанства, який проявляється в поглядах 
на людські почуття, рангові привілеї та управління країною особистим прикладом правителя.

Традиційне китайське суспільство приділяє значну увагу питанням моральних принципів, ставлячи людські почуття на перше місце у стосунках між людьми і надаючи їм елементів ритуалу, таким чином роблячи людські почуття не лише вродженою ознакою людини, але й надаючи їм прихованого значення людського обов'язку або справедливості. У конфуціанській «Книзі обрядів» зазначено: «...ритуал - це той шлях, яким перші правителі користувалися, щоб слідувати волі неба та керувати народом, тому помруть ті, хто його втратив, та врятуються ті, хто його знайшов. Що ж таке людський обов'язок? Це батьківська любов, синівський послух, опіка старшого брата молодшим, повага молодшого брата до старшого, справедливість чоловіка, покора дружини, благодіяння старших, слухняність молодших, гуманність правителів, вірність чиновників - усі десять звуться вони гуманністю і справедливістю» (Хіао, 2004, р. 22). Отже, конотація людських почуттів здійснила важливе перетворення від психологічного поняття до соціологічного. 3 цього моменту можна стверджувати, що людські почуття з родинної прихильності переросли в поняття доброти, дружби, вдячності, приязні, достоїнства тощо. Людські почуття є головною ланкою для підтримки міжособистісних відносин, а також основа для взаємодії людей і суспільства.

Починаючи з періоду Весни та Осені та періоду Воюючих Держав, патріархальна система, що розвилася на основі побуту, в якому сім'ї будувалася по батьківській родовій лінії, створила соціальний фундамент для рангових привілеїв Китаю (Li, Peng, 2001, р. 18). Кровна спорідненість в організації виробництва виконувала низку функцій: згуртування, авторитету, встановлення статусу. Ці функції відображають особливу систему розподілу та правових відносин в умовах натурального господарства, що свідчить про природність існування відмінності статусу, ієрархічного положення й багатства. Феодальна соціальна система Китаю - це продукт звичних сімейнородових реалій. Сімейна система забезпечувала міцний грунт для феодальної політичної системи, системи культури й етикету, а також бюрократичної системи. Як кажуть, «вся Піднебесна живе за одним принципом», усі дотримуються одних і тих самих етичних і політичних законів (Li, Peng, 2001, p. 20). Тому у феодальному суспільстві Китаю чиновники будь-яких рівнів мали свої певні «легітимні» привілеї, котрі згодом породили корумпованих чиновників.

У сучасному китайському суспільстві ця концепція рангових привілеїв досі приховано існує у свідомості багатьох членів партії і керівних кадрів, тому часто явище особливих привілеїв, наче привид, з'являється в кожному куточку суспільства. Наприклад: деякі члени партії і керівні кадри надмірно 
підкреслюють владу офіційних позицій, поводять себе зарозуміло і свавільно, зневажливі у ставленні до людей: як кажуть, «обличчя потворне, норов гоноровий, не підступитися і справ не вирішити» (Li, Peng, 2001, p.21). Використовуючи повноваження, надані партією і народом, вони усіляко шукають для себе вигоди. У той же час широка мережа зв'язків $є$ величезною парасолькою для такої корумпованої поведінки, котра створює унікальний механізм захисту через функціонування приватних відносин, що неминуче сприятиме розширенню корупції.

У китайському традиційному суспільстві управління особистим прикладом правителя фактично $є$ правлінням мудреця. Конфуцій вважає, що кожен повинен стримувати свою поведінку і старанно прагнути втілювати гуманність кожною своєю дією... Правління - це те саме, що справедливість, якщо правитель Цзі Канцзи чинить справедливо, хто наважиться чинити інакше? (Ма, 2002, р. 37). На думку Конфуція, політика - це шлях праведності і справедливості. «Підхід Великого вчення в тому, щоб розкрити в кожній людині притаманне їй від природи добре начало, а також, піклуючись про ближніх, допомагати їм виправитися, при цьому не зупинятися на досягнутому і прагнути довершеності» (Мa, 2002, р. 38). Згідно 3 цією цитатою, мета політики - доброчесність і моральна доброта. Менцзи також зазначав: «Тільки доброчесні повинні займати високій посади...» (Liu, 2009, p. 15). Як бачимо, правління особистим прикладом правителя засноване на існуванні ідеальної, досконалої людини. Ця концепція правління особистим прикладом правителя відповідає ідеї про природну схильність до доброти у традиційній китайській культурі. Знамените китайське «Трислів'я» починається із фрази «Людина народжується доброю», котра 3 давніх часів стала універсальним непохитним принципом китайців (Liu, 2009, p. 19).

Ідея китайців про добру природу людини суперечить уявленню про злу людську природу, що підкреслюється західним суспільством, будь то Платон та Аристотель у Стародавній Греції або вчені класичного природного права в новій історії, такі як Локк, Монтеск'є, Руссо та ін. - усі вони дотримуються думки, що «людина від природи є злою, а ще більш злою є влада» (Liu, 2009, p. 20). На думку Енгельса, «факт походження людини із тваринного світу визначив, що людина ніколи не зможе повністю позбутися тваринної сутності, тому проблема може полягати лише в тому, якою мірою їй вдасться позбутися цієї сутності» (Liu, 2009, p. 21). Отже, на основі припущення про злу людську природу на Заході змогла сформуватися інституційна структура поділу влади, а також система стримувань і противаг. Тим не менше слідування принципу доброї природи людини непомітно привело китайців до поклоніння владі і створення культу особи, а водночас i до ігнорування обмеження влади та індивіда, у кінцевому підсумку роблячи китайців залежними від влади. 
Саме через такий стан речей людям не вистачає усвідомлення своєї незалежності, натомість вони прив'язані до інших, покладаються на доброчесних мудрих політиків. Більша частина суспільства сліпо вірить усьому і має фаталістичні погляди на світ і політичну систему, для неї характерний недостатній рівень особистої суб'єктивної і конкурентної свідомості, тому цей тип управління особистим прикладом правителя перетворився у звичку i психологічну установку, глибоко вкорінену в китайську традиційну політику.

\section{Висновки}

Китайська філософська та політична традиція має власний своєрідний підхід до бачення проблеми корупції у суспільстві. Він $\epsilon$ певним протиставленням традиції, що сповідується у західній цивілізації. Передовсім це зумовлено окремішністю розвиту та своєрідністю самої китайської цивілізації, один із стовпів якої складають морально-етичні погляди конфуціанської філософії.

\section{References:}

1. Jiang, Y. (2001). Reflectionson China's Civic Awareness. Zhengxue Shehui Kexue Ban, Shandong.

2. Liu, X. (2009). The Currentsituation, Problemsand Causes of the Harmony of Chinese Political Culture. Lanzhou Xuekan, Lanzhou, pp. 15-9.

3. Li, S., Peng, D. (2001). Talking about Privilege. Wuhan Daxue Xuebao. Wuhan, pp. 18-21.

4. Ma, Q. (2002). Cultural Analysis of Corruption. Zhongguo Renmmin Daxue Xuebao, Beijing, pp. 37-38.

5. Troyan, S. (2018). 'Suchasni vidnosyny Ukraina - KNR: problemy i perspektyvy' [Current Ukraine - China relations: problems and perspectives]. Mizhnarodni vidnosyny: teoretyko-praktychni aspekty [International relations; Theory and Practical Aspects], issue 1, pp. 73-83. DOI: 10.31866/2616-745x.1.2018.133418.

6. Wang, H. (1999). Theory of Politics, Gaodeng Jiaoyu Chubanshe. Beijing.

7. Wu, L. (2008). Equal Opportunities for Citizens. Liaowang, Beijing, pp. 36-44.

8. Wu, D., Yang H. (2001). Political Ideology. Shanxi Jiaoyu Chubanshe, Taiyuan, pp. 5-59.

9. Xiao, H. (2004). The Social and Cultural Roots of Corruption. Dalian Daxue Xuebao, Dalian, pp. 22-24.

(C) Маслова А. O., 2019 